Boletín de la Sociedad Geológica Mexicana

VOLUMEN 61, NÚM. 2, 2009, P. 211-214

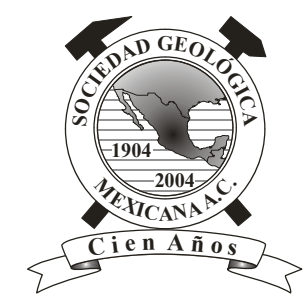

\title{
A new hermit crab (Crustacea, Anomura, Paguroidea) from the mid- Cretaceous of Navarra, Northern Spain
}

\author{
René H.B. Fraaije ${ }^{1, *}$, Barry W.M. van Bakel ${ }^{1,5}$, John W.M. Jagt ${ }^{2}$, Adiël A. Klompmaker ${ }^{3}$ and \\ Pedro Artal ${ }^{4}$ \\ ${ }^{1}$ Oertijdmuseum De Groene Poort, Bosscheweg 80, NL-5283 WB Boxtel, the Netherlands. \\ ${ }^{2}$ Natuurhistorisch Museum Maastricht (SCZ), de Bosquetplein 6-7, NL-6211 KJ Maastricht, the Netherlands. \\ ${ }^{3}$ Department of Geology, Kent State University, 221 McGilvrey Hall, Kent OH 44242, USA. \\ ${ }^{4}$ Museo Geológico del Seminario de Barcelona, Diputación 231, E-08007 Barcelona, Spain. \\ ${ }^{5}$ Nationaal Natuurhistorisch Museum [Naturalis], P.O. Box 9517, NL-2300 RA Leiden, the Netherlands. \\ *info@oertijdmuseum.nl
}

\begin{abstract}
Recent fieldwork (June 2008) in the reefal limestones near Alsasua, Navarra (northern Spain) has resulted in the discovery of a new species of diogenid hermit crab, Annuntidiogenes worfi sp. nov., which appears closely related to the type species of the genus, A. ruizdegaonai Fraaije et al., 2008, from Monte Orobe and also of mid-Cretaceous (Albian-Cenomanian) age. The new specimen represents only the third paguroid carapace of Cretaceous age to be described and formally named.
\end{abstract}

Keywords: Crustacea, Anomura, Diogenidae, Albian-Cenomanian, Spain, new taxon.

\section{Resumen}

Recientes trabajos de campo (Junio de 2008) en las calizas arrecifales cercanas a la localidad de Alsasua, Navarra (Norte de España) han proporcionado el hallazgo de una nueva especie de cangrejo ermitaño diogénido, Annuntidiogenes worfi $n$. sp., estrechamente relacionado con la especie tipo del género, A. ruizdegaonai Fraaije et al., 2008, del Monte Orobe, en depósitos adscritos al Cretácico medio (Albiense-Cenomaniense). El nuevo ejemplar es el tercer registro de un caparazón de pagúrido preservado en depósitos del Cretácico.

Palabras clave: Crustacea, Anomura, Diogenidae, Albiano-Cenomaniano, España, nuevo taxón. 


\section{Introduction}

The general palaeontology and sedimentology of AlbianCenomanian reefal deposits in the Alsasua area (Navarra, northern Spain) have previously been outlined by Ruiz de Gaona $(1943,1952,1954)$ and López-Horgue et al. (1996). Strata exposed at the disused quarry at Monte Orobe proved richly fossiliferous and yielded numerous decapod crustaceans, which were listed, described, illustrated and/ or discussed by Van Straelen (1940, 1944), Ruiz de Gaona (1943), Via Boada (1981, 1982), Gómez-Alba (1989) and López-Horgue et al. (1996). In addition, Fraaije et al. (2008) have recently erected three new genera and two new species of anomurans and brachyurans on the basis of a small faunule from Monte Orobe contained in the collections of the Institut royal des Sciences naturelles de Belgique (Brussels).

Fieldwork in the area (June 2008) has shown that, six years ago, the abandoned quarry at Monte Orobe was nearly completely filled with refuse from the then newly constructed motorway 'Autovia del Norte', which connects Alsasua and San Sebastian. However, about four kilometres south of Monte Orobe, a new decapod-rich locality has been discovered by three of us (RHBF, AAK and PA); this is an abandoned quarry at Koskobilo, which is within the same Albian-Cenomanian reefal complex, referred to as the Aldoirar reef (López-Horgue et al., 1996). In these reefal limestones, anomurans (galatheids, paguroids and porcellanids) are comparatively well represented. To date, the following taxa have been noted: Paragalathea ruizi (Van Straelen, 1940), P. straeleni (Ruiz de Gaona, 1943) (= Galathea alsasuensis Van Straelen, 1944), P. multisquamata Via Boada, 1981, Eomunidopsis navarrensis (Van Straelen, 1940), E. orobensis (Ruiz de Gaona, 1943), Annuntidiogenes ruizdegaonai Fraaije et al., 2008 and Annieporcellana dhondtae Fraaije et al., 2008. To this list we here add a second species of Annuntidiogenes from the area, with a peculiar ornament, Annuntidiogenes worfi sp. nov.

\section{Systematic palaeontology}

Order Decapoda Latreille, 1802

Infraorder Anomura MacLeay, 1838

Superfamily Paguroidea Latreille, 1802

Family Diogenidae Ortmann, 1892

Genus Annuntidiogenes Fraaije et al., 2008

Type species. Annuntidiogenes ruizdegaonai Fraaije et al., 2008, by original designation.

Diagnosis. Shield ovate, divided into distinct regions by grooves, ornamented with scabrous, irregular setal pits; long central-anterior gastric furrow (after Fraaije et al., 2008).

\section{Annuntidiogenes worfi sp. nov.}

Figure 1

Material. Holotype, and sole specimen known to date, is MGSB 75.288 (Museo Geológico del Seminario de Barcelona), an incomplete carapace from the AlbianCenomanian reefal limestones at the disused Koskobilo quarry, north of the small village of Olazti, near motorway A1 (Autovia del Norte), $2 \mathrm{~km}$ southwest of Alsasua. Carapace length (as preserved): $5.5 \mathrm{~mm}$, carapace width: $4 \mathrm{~mm}$.

Diagnosis. Shield elongated, divided into distinct regions by grooves; long central anterior gastric furrow dividing a coarsely ornamented anterior gastric region; short, narrow anterior lateral margins.

Etymology. Named after Worf, played by American actor Michael Dorn, one of the main characters in both Star Trek films (The Next Generation, Deep Space Nine) and in subsequent films based on The Next Generation, in reference to the wrinkled ornament of the anterior gastric region.

Description. Anterior region, postantennal projections and rostrum not preserved; broadly oval-shaped tumid anterior gastric region divided by a long central gastric groove, ornamented by scabrous ridges extending parallel to the groove which divides the gastric and anterior region; posterior part of gastric region smooth with irregularly distributed large setal pits, more abundant anteriorly; two small, yet distinct, ovoid tumid areas present close to the relatively small triangular posterior lateral regions; anterior lateral margins very small, smooth and elongated; posterior margin, cervical furrow and linea transversalis not preserved (for use of terminology, see Fraaije et al., 2008).

Discussion. Annuntidiogenes worfi sp. nov. differs from the similar-aged type species of the genus, A. ruizdegaonai, and from the late Maastrichtian A. sunuciorum Fraaije et al., 2008 from southern Limburg (the Netherlands), in having a wrinkled, scabrous anterior gastric region and distinctly shorter and narrower anterior lateral margins. The new species can be distinguished from the Late Jurassic pylochelids Jurapylocheles malutka and Ammopylocheles mclaughlinae (see van Bakel et al., 2008) in having curved lateral regions and a gastric process, and from the Late Jurassic parapagurid Eotylaspis wehnerae in having a scabrous ornament and a much more convex anterior gastric margin. The Late Jurassic diogenid Eopaguropsis loercheri (see van Bakel et al., 2008) is comparable in having curved lateral margins, but differs mainly in showing a shorter central gastric furrow with gastric process and in lacking carapace differentiation by grooves.

The groove pattern and differentiation into regions seen in Annuntidiogenes is most closely comparable to the carapace morphology of the extant diogenid Aniculus 


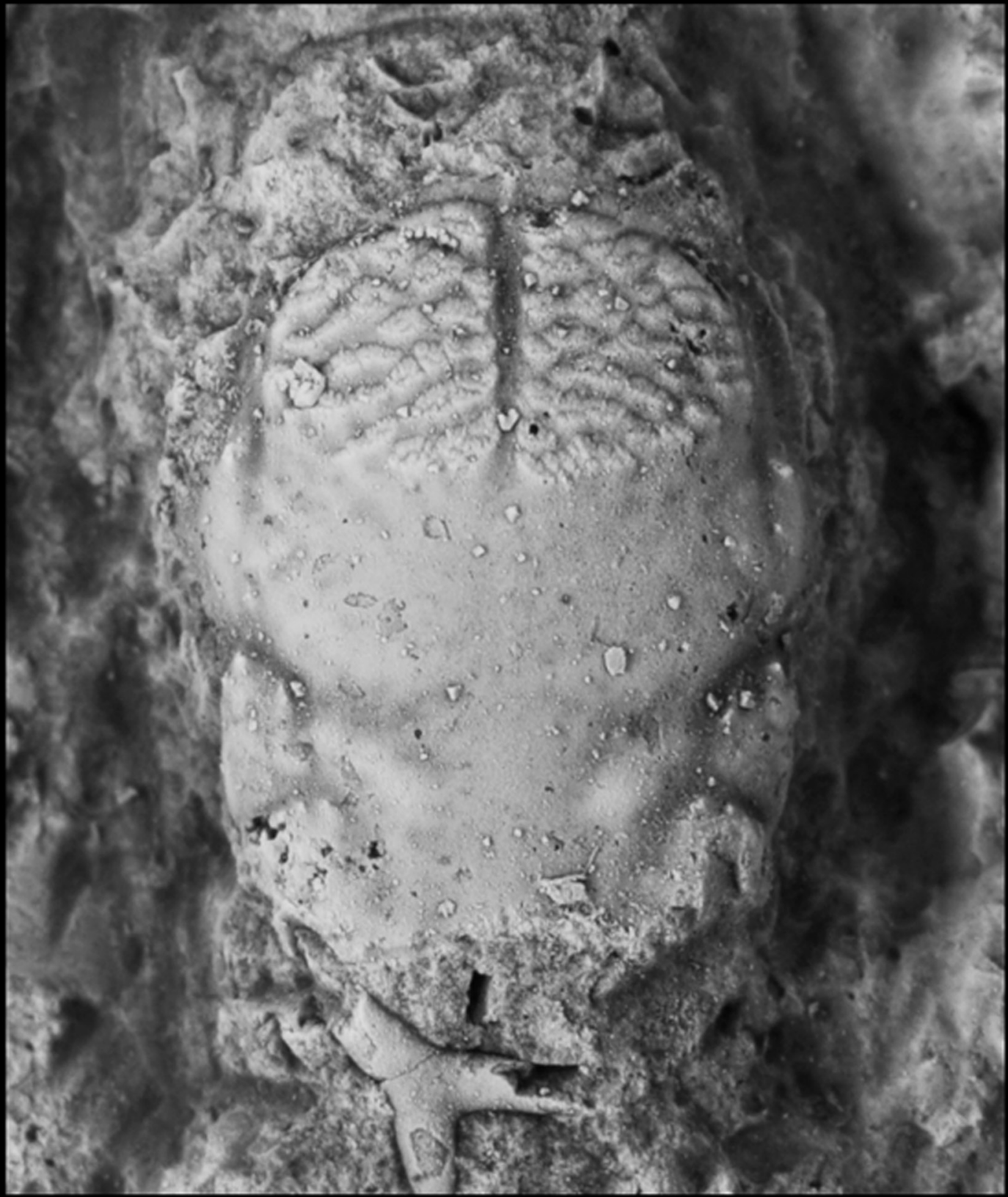

\section{$2 \mathrm{~mm}$}

Figure 1. Annuntidiogenes worfi sp. nov., holotype (MGSB 75.288) from the Albian-Cenomanian reefal limestones at the abandoned Koskobilo quarry, Alsasua area, Navarra (northern Spain). Scale bar in millimetres. 
Dana, 1852 (see Forest, 1984); the former differs in having a broader gastric region and smaller, less extensive lateral regions. Species of Aniculus inhabit shallow reefal waters of the Indo-Pacific, a setting which is closely comparable to the ecological niche Annuntidiogenes would have occupied during the Albian-Cenomanian.

The holotype of $A$. worfi sp. nov. was collected near the top of the reef, from coarse-grained calcarenites rich in algae, larger foraminifera, brachiopods, corals, small pectinid bivalves and other decapod crustaceans. Predominant in the associated decapod crustacean assemblages are galatheids (c. 80\%); dynomenids account for $c .10 \%$, goniodromitids for c. $5 \%$ ) and others for $c .5 \%$. Of special note is the fact that gastrodorids are also fairly common at the Koskobilo site, accounting for c. $1 \%$ of assemblages collected. This enigmatic group, which has recently been transferred to the Paguroidea (see van Bakel et al., 2008), was hitherto known exclusively from Upper Jurassic reefal facies in southern Germany and Poland and thus is a good example of a refugia species, or Lazarus taxon (sensu Kauffman and Harries, 1996; Harries et al., 1996). The absence of cephalopods and the paucity of gastropods and other molluscan shells potentially suitable for paguroid inhabitation in the associated fauna, could indicate that mid-Cretaceous paguroids in the Alsasua area inhabited small crevices within the coralline-algal framework of these reefs.

\section{Acknowledgements}

We thank Dr M. López-Horgue (Bilbao, Spain) for providing comparative decapod crustacean material and supply of items of literature, Prof. Dr. R.M. Feldmann (Ohio, USA), Dr. A. Garassino (Milano, Italy) and Dr. H. Karasawa (Gifu, Japan) for commenting on an earlier version of the typescript.

\section{References}

Bakel, B.W.M. van, Fraaije, R.H.B., Jagt, J.W.M., Artal, P., 2008, An unexpected diversity of Late Jurassic hermit crabs (Crustacea, Decapoda, Anomura) in central Europe: Neues Jahrbuch für Geologie und Paläontologie Abhandlungen, 250 (2), 137-156.

Dana, J.D., 1852, Crustacea: United States Exploring Expedition during the years $1838,1839,1840,1841,1842$ under the command of Charles Wilkes, U.S.N., 13, 1-1620.

Forest, J., 1984, Révision du genre Aniculus (Decapoda, Diogenidae): Crustaceana, Supplement, 8, 1-91.

Fraaije, R.H.B., van Bakel, B.W.M., Jagt, J.W.M., Artal, P., 2008, New decapod crustaceans (Anomura, Brachyura) from mid-Cretaceous reefal deposits at Monte Orobe (Navarra, northern Spain), and comments on related type-Maastrichtian material. In Steurbaut, E., Jagt, J.W.M. \& Jagt-Yazykova, E.A. (eds), Annie V. Dhondt Memorial Volume: Bulletin de l'Institut royal des Sciences naturelles de Belgique, Sciences de la Terre, 78, 193-208.
Gómez-Alba, J., 1989, Decápodos fósiles de España (Decapoda, CretácicoPleistoceno) conservados en el Museu de Geologia de Barcelona: Museu de Geologia de Barcelona, Catàleg de Colecciones, 1, $1-48$.

Harries, P.J., Kauffman, E.G. \& Hansen, T.A., 1996, Models for biotic survival following mass extinction. In Hart, M.B. (ed.), Biotic recovery from mass extinction events: Geological Society Special Publication, 102, 41-60.

Kauffman, E.G., Harries, P.J., 1996, The importance of crisis progenitors in recovery from mass extinction. In Hart, M.B. (ed.), Biotic recovery from mass extinction events: Geological Society Special Publication, 102, 15-39.

Latreille, P.A., 1802-1803, Histoire naturelle, générale et particulière, des crustacés et des insects, 3. F. Dufart, Paris, 468 pp.

López-Horgue, M.A., Manterola, D.L., Caballero, J.I.B., 1996, Evolución sedimentaria del episodio mixto carbonatado-terrígeno del Albiense Superior-Cenomaniense Inferior entre Altsasu (Nafarroa) y Asparrena (Araba): la unidad Albéniz: Príncipe de Viana, Supplemento de Ciencias, 14, 81-96.

MacLeay, W.S., 1838, On the brachyurous decapod Crustacea brought from the Cape by Dr. Smith: Illustrations of the Annulosa of South Africa; being a portion of the objects of Natural History chiefly collected during an expedition into the interior of South Africa, under the direction of Dr. Andrew Smith, in the years 1834, 1835, and 1836; fitted out by "The Cape of Good Hope Association for Exploring Central Africa". Smith, Elder and Co., London, 53-71.

Ortmann, A., 1892, Die Decapoden-Krebse des Strassburger Museums, mit besonderer Berücksichtigung der von Herrn Dr. Döderlein bei Japan und bei den Liu-Kiu-Inseln gesammelten und zur Zeit im Strassburger Museum aufbewahrten Formen, V. Theil. Die Abteilungen Galatheidea and Paguridea: Zoologische Jahrbücher, Abteilung Systematik, Ökologie und Geographie der Tiere, 6, 241-326.

Ruiz de Gaona, M., 1943, Nota sobre crustáceos decápodos de la cantera del Monte Orobe (Alsasua): Boletín de la Real Sociedad Española de Historia Natural, 40, 425-433.

Ruiz de Gaona, M., 1952, Un importantísimo yacimiento paleontológico en el Monte Orobe, Alsasua (Navarra): Príncipe de Viana, 13, 495-501.

Ruiz de Gaona, M., 1954, La fauna paleontológia de Orobe (Navarra): Boletín de la Real Sociedad Española de Historia, Toma Extraordinarío, 573-577.

Van Straelen, V., 1940, Crustacés décapodes nouveaux du Crétacique de la Navarre: Bulletin du Musée royal d'Histoire naturelle de Belgique, 16, 1-5.

Van Straelen, V., 1944, Anomoure et brachyoures du Cénomanien de la Navarre: Bulletin du Musée royal d'Histoire naturelle de Belgique, 20, 1-12.

Via Boada, L., 1981, Les crustacés décapodes du Cénomanien de Navarra (Espagne): premiers résultats de l'étude des Galatheidae [sic]. Géobios, 14, 247-251.

Via Boada, L., 1982, Les Galatheidae du Cénomanien de Navarra (Espagne): Annales de Paléontologie, 68, 107-131.

Manuscript received: September 10, 2008.

Corrected Manuscript received: October 20, 2008.

Manuscript accepted: November 10, 2008. 